\title{
Research on the Sea-Buckthorn (Hippophae rhamnoides L.) Eco-Restoration Value in Avoiding Erosion and Supporting Soil Fixation
}

\author{
Carmen Georgeta DUMITRESCU (MANOLE)* \\ University of Agronomic Science and Veterinary Medicine, 59 Marasti, sector 1, 011464, Bucharest, \\ Romania \\ * corresponding author: cdumitrescu68@yahoo.com
}

Bulletin UASVM series Agriculture 73(2)/2016

Print ISSN 1843-5246; Electronic ISSN 1843-5386

DOI 10.15835/buasvmcn-agr: 12421

\begin{abstract}
This paper approaches an issue of real importance, namely the sea-buckthorn influence on the areas attacked by erosion. We consider that this effect is mainly a result of its extremely developed root system, as well as of the nodosities formation on the roots. The study was conducted over a period of 3 years (2011-2013) in two landslides areas from Prahova and Dambovita counties, from where were collected 5 plants (from each area) in 3 repetitions. Calculating the averages regarding the plant roots depth, but also the number of root suckers and nodosities, can be easily deduced the role of these plants in soil fixation, hence their eco-restoration value.
\end{abstract}

Keywords: erosion, sea-buckthorn, soil fixation, soil restoration.

Introduction. Erosion is one of the most important factor for the soil fertility destruction, representing the most severe form of ecological and functional deterioration of those (Berca, 2008). According to the researchers, sea-buckthorn is useful in forestry for the moving lands fixation, it can withstand to soil's salts richness, which is why it can be the restoration solution for the many deforested regions where forest installation on saltrich soils encounters obstacles. The sea-buckthorn morphic field (Sheldrake, 2007) is covered with antierosional properties and health factors.

Aims and objectives. Based on the seabuckthorn plant morphological elements, but also on the research conducted so far, we have proposed to establish more accurate the morphophysiological elements that confer to this miraculous plant its eco-restoration value. Were pursued, as well, the environmental conditions that favor the development of sea-buckthorn, the interaction between sea-buckthorn and other species, but also the finding of several ways or methods to solve the major problems of land degradation.

Materials and methods. Location and general description of the sea-buckthorn populations was achieved by study visits in the survey areas, respectively Doftana Valley (Prahova) and Dambovita (Robescu, 2009) - both areas with damaged soil caused by erosion and landslides. Research was conducted on crops that initially were 5 , respectively 6 years old, pursuing the root system evolution from one year to another (20112013). It was collected a number of 10 plants ( 5 form each location) in 3 repetitions (R1, R2, R3), observing the root system development, with a direct effect on improving soil condition.

Results and Discussion. Through the observation and analysis methods used it was confirmed that Hippophae rhamnoides (sea-buckthorn) is a species with a highly developed root system, with rhizome roots, that can reach up to 20 meters long. Making comparisons in the field it appeared that the adjoining soils had different ecological characteristics according to the presence or absence of sea-buckthorn plant. Surfaces on which sea-buckthorn was found were less subjected to landslides and erosion caused by wind and water. It was found that by symbiosis between Frankia nitrogen-fixing species and sea-buckthorn (Hippophae rhamnoides) is developed an active 
Tab. 1. Average data on the root system depth and on the root-suckers and nodosities formation at seabuckthorn (Hippophae rhamnoides L.) in 2011-2013, plants collected randomly (original)

\begin{tabular}{|c|c|c|c|c|c|c|}
\hline \multirow{2}{*}{ Location } & \multirow{2}{*}{ Plants } & \multicolumn{5}{|c|}{ Dimensional characteristics } \\
\hline & & Age (years) & Depth $(\mathrm{cm})$ & Suckers (no.) & Vigor & Nodosities (no.) \\
\hline \multirow{5}{*}{ Prahova } & $\mathrm{P} 1$ & \multirow{5}{*}{5} & 150 & 2 & vigorous & 1 \\
\hline & $\mathrm{P} 2$ & & 162 & 1 & vigorous & 0 \\
\hline & $\mathrm{P} 3$ & & 156 & 4 & vigorous & 5 \\
\hline & $\mathrm{P} 4$ & & 164 & 3 & vigorous & 3 \\
\hline & P5 & & 163 & 6 & vigorous & 1 \\
\hline \multicolumn{2}{|c|}{ Average for Prahova } & \multirow{6}{*}{6} & 159 & 3.2 & vigorous & 2.0 \\
\hline \multirow{5}{*}{ Dambovita } & P6 & & 168 & 6 & vigorous & 2 \\
\hline & P7 & & 163 & 5 & vigorous & 3 \\
\hline & P8 & & 173 & 3 & vigorous & 1 \\
\hline & P9 & & 177 & 7 & vigorous & 6 \\
\hline & P10 & & 169 & 4 & vigorous & 3 \\
\hline \multicolumn{2}{|c|}{ Average for Dambovita } & & 170 & 5.0 & vigorous & 3.0 \\
\hline \multicolumn{2}{|c|}{ General average 2011} & & 164.5 & 4.1 & vigorous & 2.5 \\
\hline \multirow{5}{*}{ Prahova } & $\mathrm{P} 1$ & \multirow{5}{*}{6} & 159 & 5 & vigorous & 2 \\
\hline & $\mathrm{P} 2$ & & 164 & 7 & vigorous & 3 \\
\hline & $\mathrm{P} 3$ & & 175 & 6 & vigorous & 4 \\
\hline & P4 & & 169 & 4 & vigorous & 5 \\
\hline & $\mathrm{P} 5$ & & 178 & 5 & vigorous & 1 \\
\hline \multicolumn{2}{|c|}{ Average for Prahova } & \multirow{6}{*}{7} & 169 & 5.4 & vigorous & 3.0 \\
\hline \multirow{5}{*}{ Dambovita } & P6 & & 190 & 10 & vigorous & 6 \\
\hline & $\mathrm{P} 7$ & & 200 & 7 & vigorous & 4 \\
\hline & P8 & & 183 & 5 & vigorous & 3 \\
\hline & P9 & & 180 & 3 & vigorous & 2 \\
\hline & $\mathrm{P} 10$ & & 197 & 6 & vigorous & 4 \\
\hline \multicolumn{2}{|c|}{ Average for Dambovita } & & 190 & 6.2 & vigorous & 3.8 \\
\hline \multicolumn{2}{|c|}{ General average 2012} & & 179.5 & 5.8 & vigorous & 3.4 \\
\hline \multirow{5}{*}{ Prahova } & $\mathrm{P} 1$ & & 192 & 5 & vigorous & 3 \\
\hline & $\mathrm{P} 2$ & & 189 & 8 & vigorous & 6 \\
\hline & P3 & 7 & 188 & 6 & vigorous & 4 \\
\hline & $\mathrm{P} 4$ & & 195 & 9 & vigorous & 6 \\
\hline & P5 & & 196 & 3 & vigorous & 2 \\
\hline \multicolumn{2}{|c|}{ Average for Prahova } & & 192 & 6.2 & vigorous & 4.2 \\
\hline \multirow{5}{*}{ Dambovita } & P6 & & 193 & 9 & vigorous & 7 \\
\hline & $\mathrm{P} 7$ & & 189 & 7 & vigorous & 5 \\
\hline & P8 & 8 & 194 & 8 & vigorous & 6 \\
\hline & P9 & & 198 & 7 & vigorous & 4 \\
\hline & P10 & & 196 & 11 & vigorous & 5 \\
\hline \multicolumn{2}{|c|}{ Average for Dambovita } & & 194 & 8.4 & vigorous & 5.4 \\
\hline \multicolumn{2}{|c|}{ General average 2013} & & 193 & 7.3 & vigorous & 4.8 \\
\hline
\end{tabular}

biomass underground network, that contributes to the improvement of soil quality and stability, regardless of the slope. Concrete, we analyzed the root system of plants randomly selected from the two locations, with the purpose of presenting data on the root system development (Tab. 1.) and on the nodosities formation with Frankia.

Regarding the depth, there is a steady increase from year to year, in 2013 the value being $17.33 \%$ higher than in 2011. Similarly, the number of suckers and of nodosities increases (from 4.1 to 7.3 for suckers, from 2.5 to 4.8 for nodules), almost double in 3 years.
Conclusion. Using experimental data processing it was found that planting sea-buckthorn, in both research areas, is a mode of soil ecological restoration and it may be a viable option for solving the problems of land degradation and greening.

\section{REFERENCES}

1. Berca M (2008). Probleme de ecologia solului, Ed. Ceres, Bucuresti

2. Robescu VO (2009). Modele privind managementul reconstructiei de mediu in bazinul superior al raului Dambovita, Ed. Ceres, Bucuresti

3. Sheldrake R (2007). Rezonanta morfica. 0 noua stiinta a vietii. Ed. Firul Ariadnei, Bucuresti 